\title{
Tiron, a ROS scavenger, protects human lung cancer Calu-6 cells against antimycin A-induced cell death
}

\author{
YONG HWAN HAN and WOO HYUN PARK \\ Department of Physiology, Medical School, Institute for Medical Sciences, \\ Chonbuk National University, JeonJu 561-180, Korea
}

Received August 25, 2008; Accepted October 3, 2008

DOI: 10.3892/or_00000216

\begin{abstract}
Antimycin A (AMA) inhibits the mitochondrial electron transport between cytochromes $b$ and $c$. However, the relationship between AMA and lung cancer cells is poorly understood. In this study, we investigated the involvement of reactive oxygen species (ROS) and glutathione (GSH) in AMA-treated lung cancer Calu-6 cell death. Treatment with AMA reduced cell viability in a dose-dependent manner for 72 h. The intracellular ROS levels were decreased in Calu-6 cells treated with low doses of AMA $(10,25$ or $50 \mu \mathrm{M})$ at $72 \mathrm{~h}$. However, the levels increased in cells treated with a high dose of $100 \mu \mathrm{M}$ AMA. Levels of $\mathrm{O}_{2}{ }^{-}$- were significantly increased in AMA-treated cells at $72 \mathrm{~h}$. The increases in ROS levels including $\mathrm{O}_{2}{ }^{-}$in AMA-treated cells were observed within $10 \mathrm{~min}$. Treatment with AMA reduced the intracellular GSH content. SOD activity was up-regulated in AMA-treated Calu- 6 cells at $72 \mathrm{~h}$. However, catalase activity was down-regulated by AMA. Treatment with tiron, a ROS scavenger, reduced the intracellular ROS levels, which were associated with a partial reduction of apoptosis. Treatment with exogenous SOD and catalase significantly inhibited loss of the mitochondrial transmembrane potential $\left(\Delta \Psi_{\mathrm{m}}\right)$ in AMA-treated Calu-6 cells. In conclusion, our results suggest that the changes of intracellular ROS and GSH affect apoptosis in AMA-treated Calu-6 cells.
\end{abstract}

Correspondence to: Dr Woo Hyun Park, Department of Physiology, Medical School, Chonbuk National University, JeonJu 561-180, Republic of Korea

E-mail: parkwh71@chonbuk.ac.kr

Abbreviations: AMA, antimycin A; ROS, reactive oxygen species; $\mathrm{NADPH}$, nicotine adenine diphosphate; $\mathrm{XO}$, xanthine oxidase; SOD, superoxide dismutase; FBS, fetal bovine serum; PBS, phosphate buffer saline; FITC, fluorescein isothiocyanate; $\mathrm{H}_{2}$ DCFDA, 2', 7'dichlorodihydrofluorescein diacetate; DHE, dihydroethidium; GSH, glutathione; CMFDA, 5-chloromethylfluorescein diacetate; MTT, 3(4,5-dimethylthiazol-2-yl)-2,5-diphenyltetrazolium bromide; PI, propidium iodide

Key words: antimycin A, reactive oxygen species, cell cycle, apoptosis, mitochondria, Calu-6

\section{Introduction}

Reactive oxygen species (ROS) include hydrogen peroxide $\left(\mathrm{H}_{2} \mathrm{O}_{2}\right)$, superoxide anion $\left(\mathrm{O}_{2}{ }^{-}\right)$and hydroxyl radical $\left({ }^{\circ} \mathrm{OH}\right)$. These molecules have recently been implicated in regulating many important cellular events, including transcriptional factor activation, gene expression, differentiation and cell proliferation (1-3). ROS are formed as by-products of mitochondrial respiration or the action of oxidases, including nicotine adenine diphosphate (NADPH), xanthine (XO) and certain arachidonic acid oxygenases (1). A change in the redox state of a tissue implies a change in ROS generation or metabolism. The principal metabolic pathways include superoxide dismutase (SOD), which is expressed as extracellular, intracellular and mitochondrial isoforms. These isoforms metabolize $\mathrm{O}_{2}{ }^{-}$to $\mathrm{H}_{2} \mathrm{O}_{2}$. Further metabolism by peroxidases, which include catalase and glutathione (GSH), yields $\mathrm{O}_{2}$ and $\mathrm{H}_{2} \mathrm{O}$ (4). GSH is the main non-protein antioxidant in the cell and provides electrons for enzymes such as glutathione peroxidase, which reduce $\mathrm{H}_{2} \mathrm{O}_{2}$ to $\mathrm{H}_{2} \mathrm{O}$. GSH has been shown to be crucial for cell proliferation, cell cycle progression and apoptosis $(5,6)$ and is known to protect cells from toxic insult by detoxifying toxic metabolites of drugs and ROS (7). Although cells possess antioxidant systems to control their redox state, which is important for their survival, excessive ROS production can be induced and give rise to the activation of events that lead to death or survival in different cell types $(2,8-11)$. The exact mechanisms involved in cell death induced by ROS are not fully understood and the protective effect of certain antioxidants remains controversial.

Antimycin A (AMA) is a product that is predominantly composed of antimycin A1 and A3, which are derived from Streptomyces kitazawensis (12). AMA inhibits succinate and NADH oxidase, and inhibits the mitochondrial electron transport between cytochromes $b$ and $c$ (13-16). The inhibition of electron transport causes a collapse of the proton gradient across the mitochondrial inner membrane, thereby breaking down the mitochondrial membrane potential $\left(\Delta \Psi_{\mathrm{m}}\right)(13,15,17)$. This inhibition results in ROS production $(17,18)$. Evidence indicates that either the presence of ROS or the collapse of mitochondrial membrane potential $\left(\Delta \Psi_{\mathrm{m}}\right)$ opens the mitochondrial permeability transition pore, which is associated with the release of proapoptotic molecules such as cytochrome $\mathrm{c}$ into the cytoplasm (19-21). Since AMA acts 
directly on the mitochondria, AMA-induced apoptosis has been reported in many experiments, including our report on As4.1 juxtaglomerular cells (22-27).

Lung cancer is the major cause of cancer death in developed countries. There are various novel therapeutic strategies currently under consideration, as the clinical use of cytotoxic drugs is limited due to intrinsic or acquired resistance and toxicity (28). A better understanding of the molecular mechanisms of cytotoxic drug action has shed light on the treatment of lung cancer, and novel agents that target specific intracellular pathways related to the distinctive properties of cancer cells continue to be developed. Specifically, research on mitochondrial damage agents including AMA in lung cancer cells would inform the new drug development about the treatment of lung cancer patients.

In the present study, we assessed the involvement of ROS and GSH in AMA-induced Calu- 6 cell death and investigated whether ROS scavengers rescue these cells from AMAinduced cell death.

\section{Materials and methods}

Cell culture. A human pulmonary adenocarcinoma Calu-6 cell line was obtained from the ATCC and maintained in a humidified incubator with $5 \% \mathrm{CO}_{2}$ at $37^{\circ} \mathrm{C}$. The cells were cultured in RPMI-1640 supplemented with $10 \%$ fetal bovine serum (FBS) and 1\% penicillin-streptomycin (Gibco BRL, Grand Island, NY). They were routinely grown in 100-mm plastic tissue culture dishes (Nunc, Roskilde, Denmark) and harvested with a solution of trypsin-EDTA while in the logarithmic phase. Cells were maintained in these culture conditions for all experiments.

Reagents. AMA was purchased from Sigma-Aldrich Chemical Company (St. Louis, MO). AMA was dissolved in ethanol at $200 \mathrm{mM}$ as a stock solution. The cell-permeable $\mathrm{O}_{2}{ }^{\circ}$ scavengers, 4-hydroxy-TEMPO (4-hydroxyl-2,2,6,6-tetramethylpierydine-1-oxyl) (tempol), 4,5-dihydroxyl-1,3benzededisulfonic acid (tiron) and 1-[2,3,4-trimethoxibenzyl]-piperazine (trimetazidine) were obtained from Sigma. These were dissolved in water or ethanol solution buffer at $100 \mathrm{mM}$ as a stock solution, which was also used as a control vehicle. SOD and catalase were obtained from Sigma and dissolved in $50 \mathrm{mM}$ potassium phosphate buffer at $4733 \mathrm{U} / \mathrm{ml}$. The stock solution was wrapped in foil and kept at $4^{\circ} \mathrm{C}$ or $-20^{\circ} \mathrm{C}$.

Cell viability assay. The cell viability effect of AMA on Calu-6 cells was determined by measuring the 3-(4,5dimethylthiazol-2-yl)-2,5-diphenyltetrazolium bromide (MTT) dye absorbance of living cells as described previously (29). In brief, cells $\left(5 \times 10^{4} /\right.$ well $)$ were seeded in 96 -well microtiter plates in the presence of the designated doses of AMA with or without scavenger (tempol, tiron or trimetazidine). After exposure to AMA for $72 \mathrm{~h}, 50 \mu \mathrm{l}$ of MTT (Sigma) solution $(2 \mathrm{mg} / \mathrm{ml}$ in PBS) were added to each well, and the plates were incubated for an additional $3 \mathrm{~h}$ at $37^{\circ} \mathrm{C}$. MTT solution in medium was aspirated off. To achieve solubilization of the formazan crystals formed in viable cells, $200 \mu 1$ of DMSO were added to each well. The optical density of each well was measured at $570 \mathrm{~nm}$ using a microplate reader (Spectra MAX 340, Molecular Devices Co., Sunnyvale, CA, USA). Each plate contained multiple wells at a given experimental condition and multiple control wells. This procedure was replicated for 2-4 plates/condition.

\section{Measurement of intracellular non-specific ROS and $\mathrm{O}_{2}{ }^{-}$} concentration. Intracellular non-specific ROS such as $\mathrm{H}_{2} \mathrm{O}_{2}$, $\cdot \mathrm{OH}$ and $\mathrm{ONOO}^{\cdot}$ were detected by means of the oxidationsensitive fluorescent probe dye, 2',7'-dichlorodihydrofluorescein diacetate $\left(\mathrm{H}_{2} \mathrm{DCFDA}\right)$ (Invitrogen Molecular Probes, Eugene, OR). $\mathrm{H}_{2}$ DCFDA was deacetylated intracellularly by non-specific esterase, which was then oxidized by cellular peroxides, yielding 2,7-dichlorofluorescein (DCF), a fluorescent compound $(\mathrm{Ex} / \mathrm{Em}=495 / 529 \mathrm{~nm})$. DCF is poorly selective for the superoxide anion radical $\left(\mathrm{O}_{2}{ }^{-}\right)$. In contrast, dihydroethidium $(\mathrm{DHE})(\mathrm{Ex} / \mathrm{Em}=518 / 605 \mathrm{~nm})$ (Invitrogen Molecular Probes) is a fluorogenic probe that is highly selective for $\mathrm{O}_{2}{ }^{-}$among ROS. It is cell-permeable and reacts with superoxide anion to form ethidium, which in turn intercalates in the deoxyribonucleic acid, thereby exhibiting a red fluorescence. In brief, $1 \times 10^{6}$ cells were incubated with the designated doses of AMA with or without ROS scavenger (tempol, tiron, trimetazidine, SOD or catalase) for $72 \mathrm{~h}$. They were then washed in PBS and incubated with $20 \mu \mathrm{M} \mathrm{H}_{2} \mathrm{DCFDA}$ or $5 \mu \mathrm{M} \mathrm{DHE}$ at $37^{\circ} \mathrm{C}$ for $30 \mathrm{~min}$. DCF fluorescence and red fluorescence were detected using a FACStar flow cytometer (Becton-Dickinson). For each sample, 10,000 events were collected. ROS and $\mathrm{O}_{2}{ }^{-*}$ levels were expressed as mean fluorescence intensity (MFI), which was calculated by CellQuest software.

Measurement of cellular catalase activity. The level of cellular catalase enzyme activity was measured using a catalase assay kit from Sigma-Aldrich Chemical Company. In brief, $1 \times 10^{6}$ cells were incubated with $50 \mu \mathrm{M}$ AMA for 1 or $72 \mathrm{~h}$. The cells were washed with PBS and suspended in 5 volumes of lysis buffer [20 mM HEPES ( $\mathrm{pH} 7.9$ ), 20\% glycerol, $200 \mathrm{mM} \mathrm{KCl,} 0.5 \mathrm{mM}$ EDTA, 0.5\% NP40, $0.5 \mathrm{mM}$ DTT and $1 \%$ protease inhibitor cocktail (from Sigma)]. The lysates were then collected and stored at $-20^{\circ} \mathrm{C}$ until further use. The supernatant protein concentration was determined by the Bradford method. Supernatant samples containing $30 \mu \mathrm{g}$ of total protein were used to determine catalase enzyme activity. These were added to a microcentrifuge tube with the appropriate volume of assay buffer $\left(50 \mathrm{mM} \mathrm{KH}_{2} \mathrm{PO}_{4} / 50 \mathrm{mM}\right.$ $\mathrm{Na}_{2} \mathrm{HPO}_{4}, \mathrm{pH}$ 7.0). The reaction was initiated by the addition of $200 \mathrm{mM} \mathrm{H}_{2} \mathrm{O}_{2}$ solution at $25^{\circ} \mathrm{C}$ for $5 \mathrm{~min}$, and was finished by the addition of stop solution. A small amount of the above reaction mixture was removed, added to another microcentrifuge tube with the color reagent $(150 \mathrm{mM}$ potassium phosphate buffer, $\mathrm{pH} 7.0$, containing $0.25 \mathrm{mM} 4$-aminoantipyrine, $2 \mathrm{mM}$ 3,5-dichloro-2-hydroxybenzenesulfonic acid and the peroxidase solution), and were incubated to convert the color reagent to a red quinoneimine color at $25^{\circ} \mathrm{C}$ for $\sim 10 \mathrm{~min}$. The dye was measured at $520 \mathrm{nM}$ using a microplate reader (Spectra MAX 340, Molecular Devices Co.). A standard curve of catalase solution (5 U-50 U/ml) was run for quantification. 
Measurement of cellular SOD activity. The level of cellular SOD enzyme activity was measured using a SOD Assay KitWST (Fluka Co, Milwaukee, WI, USA), which allows very convenient SOD assaying by utilizing a highly water-soluble tetrazolium salt, WST-1 (2-(4-lodophenyl)-3-(4-nitrophenyl)5-(2,4-disulfophenyl)-2H-tetrazolium and monosodium salt), which produces a water-soluble formazan dye upon reduction with a superoxide anion. In brief, $1 \times 10^{6}$ cells were incubated with $50 \mu \mathrm{M}$ AMA for 1 or $72 \mathrm{~h}$. The cells were washed in PBS and suspended in 5 volumes of lysis buffer $[20 \mathrm{mM}$ HEPES (pH 7.9), 20\% glycerol, $200 \mathrm{mM} \mathrm{KCl,} 0.5 \mathrm{mM}$ EDTA, $0.5 \%$ NP40, $0.5 \mathrm{mM}$ DTT and $1 \%$ protease inhibitor cocktail (from Sigma)]. The lysates were then collected and stored at $-20^{\circ} \mathrm{C}$ until further use. The supernatant protein concentration was determined by the Bradford method. Supernatant samples containing $30 \mu \mathrm{g}$ of total protein were used to determine SOD enzyme activity. These were added to each well in 96-well microtiter plates (Nunc) with WST and enzyme working solution, and were incubated to produce a water-soluble formazan dye at $25^{\circ} \mathrm{C}$ for $10 \mathrm{~min}$. The WST-1 formazan was measured at $450 \mathrm{nM}$ using a microplate reader (Spectra MAX 340, Molecular Devices Co.). A standard curve of SOD solution $(5 \mathrm{U}-50 \mathrm{U} / \mathrm{ml}$ ) was run for quantification.

Detection of the intracellular glutathione (GSH). Cellular GSH levels were analyzed using 5-chloromethylfluorescein diacetate (CMFDA, Molecular Probes). CMFDA (Ex/Em = $492 / 517 \mathrm{~nm})$ is a membrane-permeable dye $(30,31)$. In brief, $1 \times 10^{6}$ cells were incubated with $50 \mu \mathrm{M}$ AMA with or without ROS scavenger (tempol, tiron, trimetazidine, SOD or catalase) for $72 \mathrm{~h}$. They were then washed with PBS and incubated with $5 \mu \mathrm{M}$ CMFDA at $37^{\circ} \mathrm{C}$ for $30 \mathrm{~min}$. Cytoplasmic esterases convert non-fluorescent CMFDA to fluorescent 5-chloromethylfluorescein, which reacts with glutathione. To verify the disruption of the plasma membrane in these cells, propidium iodide (PI $1 \mu \mathrm{g} / \mathrm{ml}$; Ex/Em = 488/ $617 \mathrm{~nm}$; Sigma-Aldrich) was added. CMF fluorescence and PI staining intensity were measured using a FACStar flow cytometer (Becton-Dickinson) and CellQuest software. For each sample, 10,000 events were collected.

Sub-Gl analysis. The amount of sub-G1 cells was determined by staining DNA with PI as described previously (32). PI is a fluorescent biomolecule that stains DNA. In brief, $1 \times 10^{6}$ cells were incubated with $50 \mu \mathrm{M}$ AMA with or without ROS scavengers (tempol, tiron or trimetazidine) for $72 \mathrm{~h}$. They were then washed with phosphate-buffered saline (PBS) and fixed in $70 \%$ ethanol. They were washed again with PBS and incubated with PI $(10 \mu \mathrm{g} / \mathrm{ml})$ with the simultaneous treatment of RNase at $37^{\circ} \mathrm{C}$ for $30 \mathrm{~min}$. The percent of cells containing sub-G1 DNA content was measured using a FACStar flow cytometer (Becton-Dickinson) and analyzed with lysis II and CellFIT software (Becton-Dickinson).

Annexin $V$ staining. Apoptosis was determined by staining cells with annexin V-fluorescein isothiocyanate (FITC) $(\mathrm{Ex} / \mathrm{Em}=495 / 529 \mathrm{~nm})$, because annexin $\mathrm{V}$ is used to measure the externalization of phosphatidylserine during apoptosis and, detects cells in the early phases of apoptosis. Cells $\left(1 \times 10^{6}\right)$ were incubated with $50 \mu \mathrm{M}$ AMA with or without ROS scavenger (tempol, tiron, trimetazidine, SOD or catalase) for $72 \mathrm{~h}$. They were washed twice with cold PBS and resuspended in $500 \mu 1$ of binding buffer $(10 \mathrm{mM}$ HEPES/NaOH pH 7.4, $140 \mathrm{mM} \mathrm{NaCl}$ and $2.5 \mathrm{mM} \mathrm{CaCl}_{2}$ ) at $1 \times 10^{6}$ cells $/ \mathrm{ml}$. Annexin V-FITC (5 $\left.\mu \mathrm{l}\right)$ (PharMingen, USA) was then added to these cells, which were analyzed with a FACStar flow cytometer (Becton-Dickinson).

Measurement of mitochondrial membrane potential $\left(\Delta \Psi_{m}\right)$. The mitochondrial membrane potential was monitored using Rhodamine $123($ Ex/Em = 507/529 nm), a cell-permeable cationic dye that preferentially enters mitochondria due to the highly negative mitochondrial membrane potential $\left(\Delta \Psi_{\mathrm{m}}\right)$. Depolarization of the mitochondrial membrane potential $\left(\Delta \Psi_{\mathrm{m}}\right)$ results in loss of Rhodamine 123 from the mitochondria and a decrease in intracellular fluorescence. Cells $\left(1 \times 10^{6}\right)$ were incubated with $50 \mu \mathrm{M}$ AMA with or without ROS scavenger (tempol, Trion, trimetazidine, SOD or catalase) for $72 \mathrm{~h}$. They were washed twice with PBS and incubated with Rhodamine 123 [0.1 (g/ml; Sigma) $]$ at $37^{\circ} \mathrm{C}$ for $30 \mathrm{~min}$. Rhodamine 123 staining intensity was determined by flow cytometry.

Statistical analysis. The results presented the were means of at least three independent experiments; bar, SD. Microsoft Excel or Instat software (GraphPad Prism4, USA) was used to analyze the data. Student's t-test or one-way analysis of variance (ANOVA), with post hoc analysis using Tukey's multiple comparison test, was used for parametric data. Statistical significance was defined as $\mathrm{P}<0.05$.

\section{Results}

AMA effect on cell viability, intracellular ROS and GSH levels in Calu-6 cells. We examined the effect of AMA on the viability of Calu- 6 cells using MTT assay. Treatment with AMA reduced the cell viability in a dose-dependent manner for $72 \mathrm{~h}$ (Fig. 1A). The viability was completely decreased at $100 \mu \mathrm{M}$ of AMA (Fig. 1A). To assess levels of intracellular non-specific ROS in AMA-treated Calu-6 cells, we used $\mathrm{H}_{2}$ DCFDA fluorescence. As shown in Fig. 1B, the intracellular ROS levels decreased in Calu- 6 cells treated with low doses of AMA $(10,25$ or $50 \mu \mathrm{M})$ at $72 \mathrm{~h}$. However, the levels in cells treated with a high dose of $100 \mu \mathrm{M}$ AMA increased. The increased patterns of ROS levels by AMA were clearly detected within $10 \mathrm{~min}$ (Fig. 1C) and an increase in ROS levels lasted until the tested time of $5 \mathrm{~h}$. Maximum levels of ROS were reached at $\sim 180$ min after treatment with $250 \mu \mathrm{M}$ AMA. Intracellular $\mathrm{O}_{2}{ }^{-}$levels increased in the AMA-treated Calu- 6 cells in a dose-dependent manner at $72 \mathrm{~h}$ (Fig. 1D). The level of the intracellular $\mathrm{O}_{2}{ }^{-}$in Calu-6 cells treated with $100 \mu \mathrm{M}$ AMA increased $\sim 3.5$ times, as compared to that of the control cells (Fig. 1D). In addition, the accumulation of $\mathrm{O}_{2}{ }^{-}$was observed at an early time point of $10 \mathrm{~min}$ in AMA-treated cells (Fig. 1E). The maximum level of $\mathrm{O}_{2}{ }^{-}$was reached at $\sim 60$ min after treatment with $70 \mu \mathrm{M}$ AMA and was $\sim 15$ times higher than that of the control cells. The levels then decreased after $\sim 60 \mathrm{~min}$. 
A

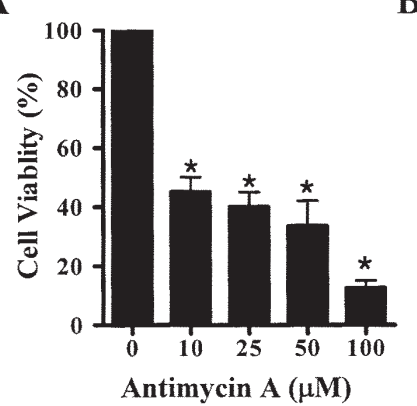

C

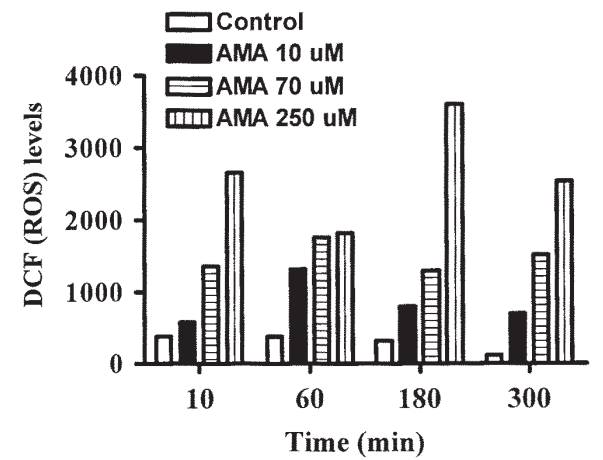

D

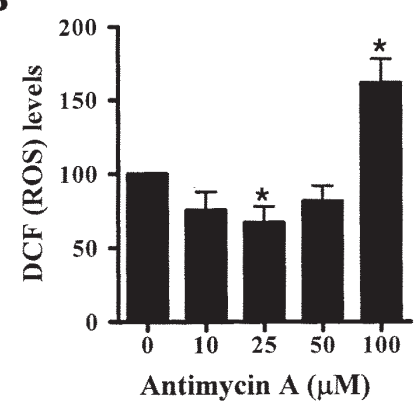

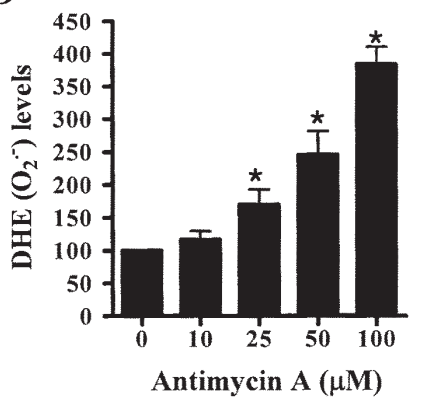

$\mathbf{E}$

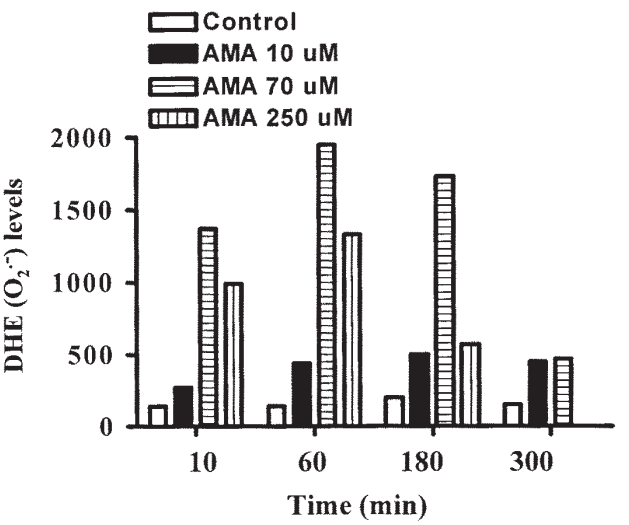

Figure 1. AMA effect on cell viability and intracellular ROS levels in Calu-6 cells. Exponentially-growing cells were treated with the indicated amounts of AMA for $72 \mathrm{~h}$ (A, B and D) or the short time periods (C and E). (A) The viability of Calu-6 cells was assessed by MTT assay. (B and C) The intracellular ROS levels were determined by a FACStar flow cytometer as described in Materials and methods. The graphs show the levels of mean DCF fluorescence (\% of control cells). (D and E) The graphs show the levels of mean DHE $\left(\mathrm{O}_{2}{ }^{-}\right)$fluorescence (\% of control cells). ${ }^{*} \mathrm{P}<0.05$ as compared with the control group cells.

A

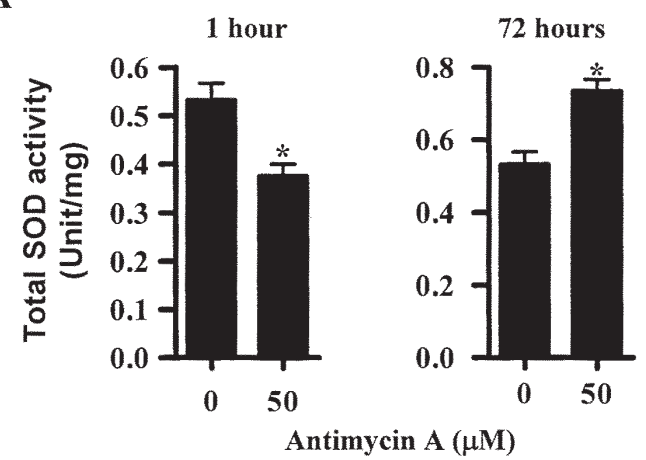

B

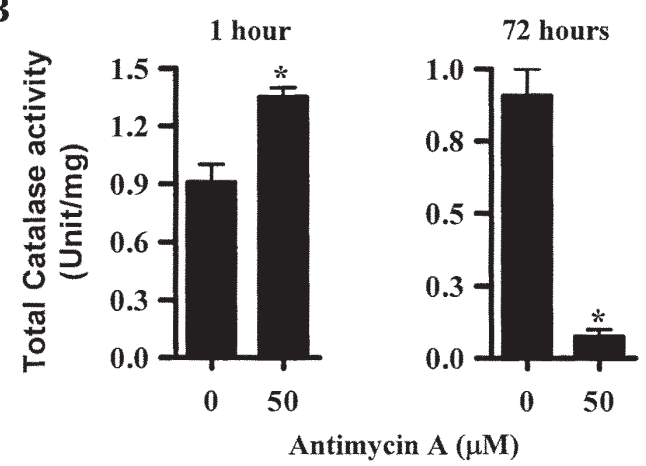

Figure 2. AMA effects of on activities of SOD and catalase in Calu- 6 cells Exponentially-growing cells were treated with $50 \mu \mathrm{M}$ AMA for 1 or $72 \mathrm{~h}$. (A) The graphs show the activity of total SOD in AMA-treated and -untreated Calu-6 cells. (B) The graphs show the changes of catalase activity by AMA. ${ }^{*} \mathrm{P}<0.05$ as compared with the control group cells.
SOD, which catalyzes the dismutation of $\mathrm{O}_{2}{ }^{-}$into $\mathrm{H}_{2} \mathrm{O}_{2}$ and molecular oxygen, is one of the most important antioxidative enzymes. Catalase then metabolizes $\mathrm{H}_{2} \mathrm{O}_{2}$ to $\mathrm{O}_{2}$ and $\mathrm{H}_{2} \mathrm{O}$. As shown in Fig. 2A, SOD activity was decreased in $50 \mu \mathrm{M}$ AMA-treated cells at the early time phase of $1 \mathrm{~h}$, but was increased at the later time phase of $72 \mathrm{~h}$, as compared with that from the control cells. Conversely, treatment with AMA increased catalase activity at $1 \mathrm{~h}$ but decreased the activity at $72 \mathrm{~h}$ (Fig. 2B).

We analyzed changes of the GSH level in Calu- 6 cells using CMF fluorescence. The M1 population of Calu- 6 cells showed the lower levels of the intracellular GSH content (Fig. 3A). AMA significantly elevated the percentages of Calu- 6 cells residing in the M1 region in a dose-dependent manner at $72 \mathrm{~h}$ (Fig. 3A), pointing to the depletion of intracellular GSH in Calu-6 cells following treatment with AMA. Decrease of the intracellular GSH content (mean CMF fluorescence) was also observed at the early time points of 25 or 50 min in 70 or $250 \mu \mathrm{M}$ AMA-treated cells (data not shown). We stained these cells with PI to verify the disruption of the plasma membrane. As shown in Fig. 3B, many CMF-negative cells treated with $100 \mu \mathrm{M}$ AMA for $72 \mathrm{~h}$ were PI positive, indicating that the cells showing GSH depletion were dead. The proportion of CMF-negative and PI-positive cells increased in a dose-dependent manner (Fig. 3B).

Effects of ROS scavengers on ROS, GSH levels and cell viability in AMA-treated Calu- 6 cells. To determine whether ROS levels and GSH depletion in AMA-treated Calu-6 

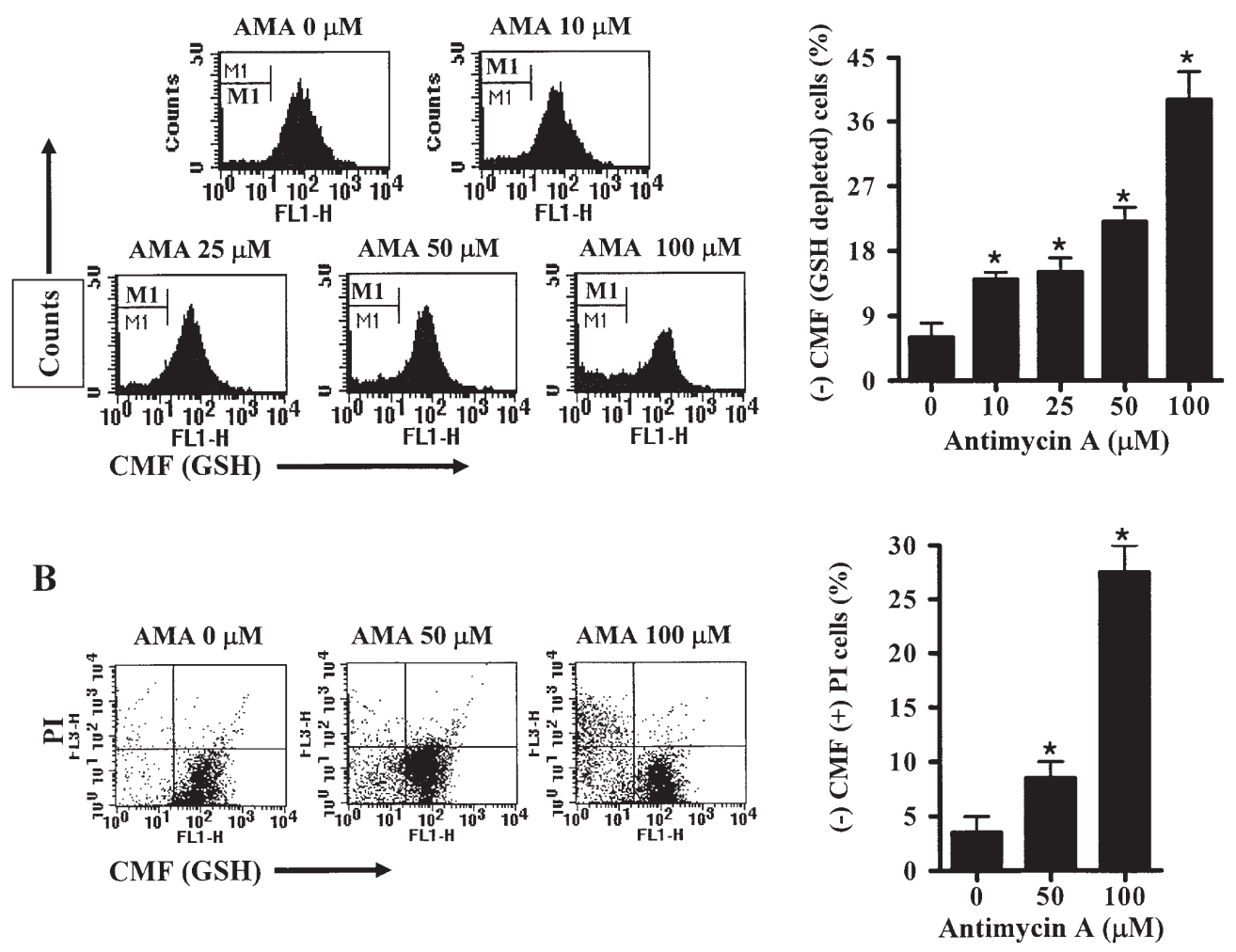

Figure 3. AMA effects on GSH content and cell viability in Calu- 6 cells. Exponentially-growing cells were treated with the indicated amounts of AMA for 72 h. (A) The intracellular GSH levels were determined by a FACStar flow cytometer as described in Materials and methods. The graph shows the CMFnegative fluorescence (M1 region; GSH depleted) cell percentage in AMA-treated Calu-6 cells. (B) CMF and PI (cell viability) fluorescence cells were measured using a FACStar flow cytometer. The graph shows the CMF-negative and PI-positive cell percentage. *P<0.05 as compared with AMA-untreated control group.

A

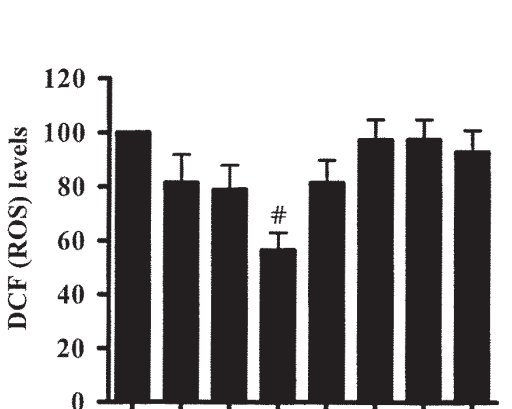

AMA $50 \mu \mathrm{M}:-++++-$

Tempol $200 \mu \mathrm{M}:-\ldots+-\ldots+$

Trime $200 \mu \mathrm{M}$ :
B

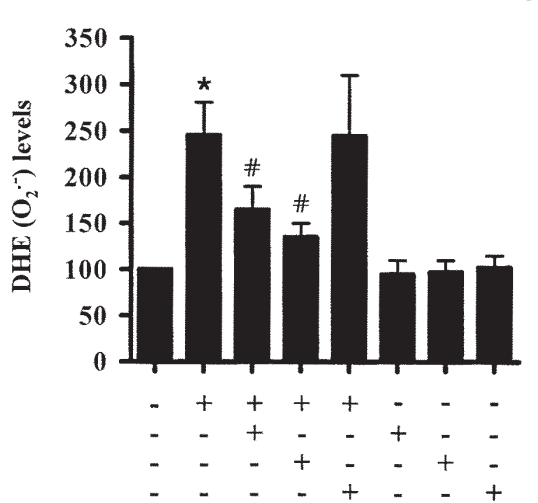

C

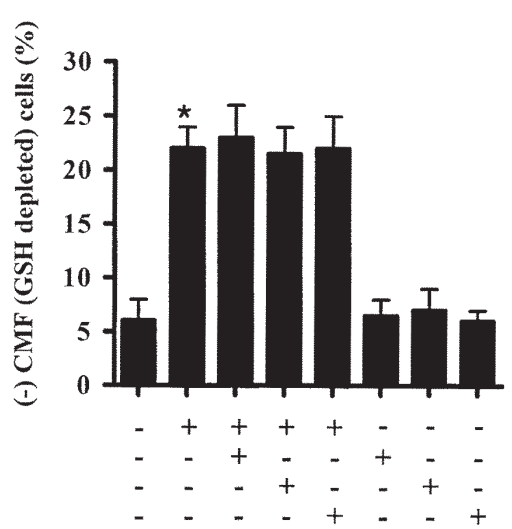

Figure 4. Effects of ROS scavengers on the intracellular ROS and GSH levels in AMA-treated Calu-6 cells. Exponentially-growing cells were treated with $200 \mu \mathrm{M}$ ROS scavengers in addition to $50 \mu \mathrm{M}$ AMA for $72 \mathrm{~h}$. The graphs show (A) the levels of mean DCF fluorescence, (B) mean DHE fluorescence (\% of control cells) and (C) the CMF-negative fluorescence (GSH depleted) cell percentages. ${ }^{*} \mathrm{P}<0.05$ as compared with the control group cells. ${ }^{\#} \mathrm{P}<0.05$ as compared with cells treated with only AMA.

cells are changed by ROS scavengers, cell-permeable ROS scavengers, tempol or tiron (33-35), were co-incubated with AMA-treated Calu- 6 cells for $72 \mathrm{~h}$. An anti-ischemic and metabolic agent, trimetazidine was also used as an indirect antioxidant $(36,37)$. We used $50 \mu \mathrm{M}$ AMA for these experiments because $100 \mu \mathrm{M}$ AMA induced cell death. As shown in Fig. 4A, the ROS level in AMA-treated cells was not significantly altered by $200 \mu \mathrm{M}$ tempol or trimetazidine. However, treatment with $200 \mu \mathrm{M}$ tiron significantly decreased the ROS level in these cells. Tempol and tiron significantly decreased the $\mathrm{O}_{2}{ }^{-}$- levels in AMA-treated cells but trimetazidine did not (Fig. 4B). In addition, none of the scavengers 
A

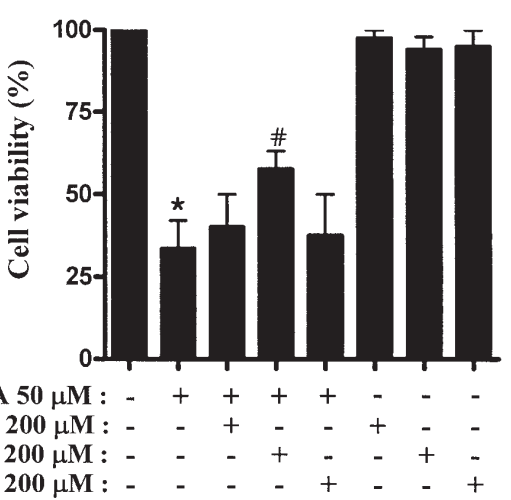

C

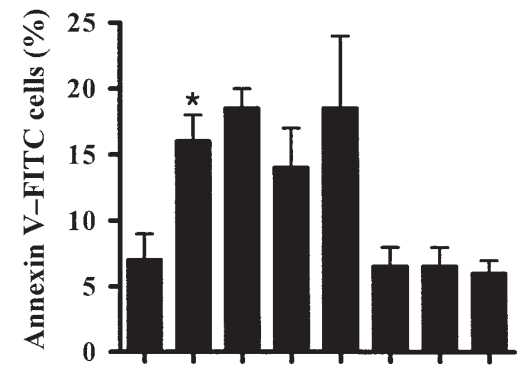

AMA $50 \mu \mathrm{M}:-\quad++++-$

Tempol $200 \mu \mathrm{M}:-\quad+\quad-\quad+\quad-$

Tiron $200 \mu \mathrm{M}:-\quad-\quad+\quad+\quad-$

Trime. $200 \mu \mathrm{M}:-\quad-\quad-\quad-\quad+\quad-\quad-\quad+$
B

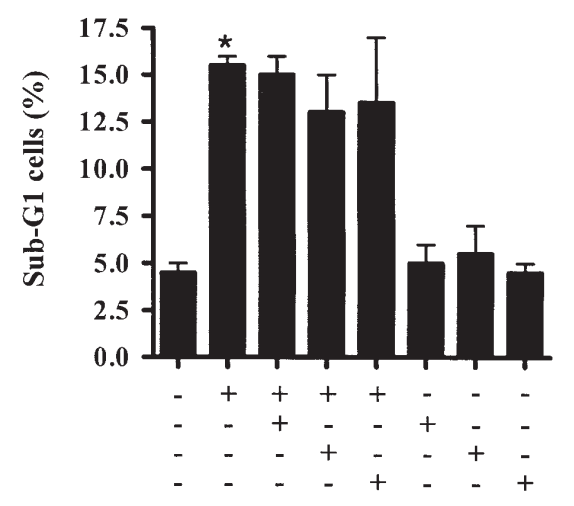

D

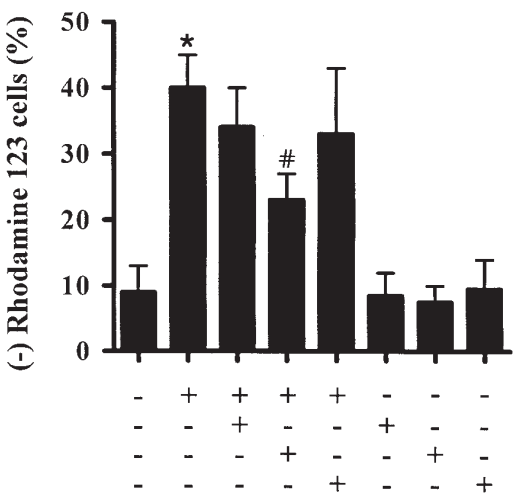

Figure 5. Effects of ROS scavengers on AMA-induced cell death. Exponentially-growing cells were treated with $200 \mu \mathrm{M}$ ROS scavengers in addition to $50 \mu \mathrm{M}$ AMA for $72 \mathrm{~h}$. A, The viability of Calu- 6 cells was assessed by MTT assay. (A-C) Sub-G1, annexin V-positive and Rhodamine 123-negative cells were measured using flow cytometry in Materials and methods. The graphs show the (A) sub-G1, (B) annexin V-positive and (C) Rhodamine 123-negative cell percentages. ${ }^{*} \mathrm{P}<0.05$ as compared with the control group cells. ${ }^{*} \mathrm{P}<0.05$ as compared with cells treated with only AMA.

prevented the depletion of GSH content in AMA-treated Calu-6 cells (Fig. 4C). We did not use a higher concentration $(>200 \mu \mathrm{M})$ of these scavengers due to their toxicity.

We then examined whether ROS scavengers rescue Calu-6 cells from AMA-induced cell death. Only tiron slightly recovered the viability of AMA-treated Calu- 6 cells (Fig. 5A) and decreased the number of sub-G1 and annexin V-positive cells in these cells (Fig. 5B and C). Regarding the mitochondrial membrane potential $\left(\Delta \Psi_{\mathrm{m}}\right)$, tiron significantly prevented loss of the mitochondrial membrane potential $\left(\Delta \Psi_{\mathrm{m}}\right)$ in AMA-treated cells, while tempol and trimetazidine slightly prevented the loss (Fig. 5D).

SOD and catalase effects on ROS, GSH levels and cell viability in AMA-treated Calu-6 cells. To determine whether ROS levels and GSH depletion in AMA-treated Calu-6 cells are changed by treatment with exogenous SOD or catalase, Calu-6 cells were treated with AMA in the presence or absence of SOD $(30 \mathrm{U} / \mathrm{ml})$ or catalase $(30 \mathrm{U} / \mathrm{ml})$ for $72 \mathrm{~h}$. As shown in Fig. 6A and B, SOD or catalase did not change the ROS levels including intracellular $\mathrm{O}_{2}{ }^{-}$levels in AMA-treated Calu- 6 cells, nor did they prevent the depletion of GSH content in Calu-6 cells treated with AMA (Fig. 6C).

We examined whether SOD or catalase protects Calu-6 cells against AMA insult. They slightly increased the viability of AMA-treated Calu-6 cells (Fig. 6D). Treatment with SOD or catalase did not decrease the number of annexin $\mathrm{V}$ positive staining cells induced by AMA (Fig. 6E). However, SOD or catalase significantly reduced loss of the mitochondrial transmembrane potential $\left(\Delta \Psi_{\mathrm{m}}\right)$ in these cells (Fig. 6F). When we used the amounts of SOD $(60 \mathrm{U} / \mathrm{ml})$ and catalase $(60 \mathrm{U} / \mathrm{ml})$ in the experiment, the dose showed no differences in ROS levels, GSH depletion and cell death in comparison with SOD $(30 \mathrm{U} / \mathrm{ml})$ and catalase $(30 \mathrm{U} / \mathrm{ml})$ (data not shown).

\section{Discussion}

In this study, we focused on the involvement of ROS and GSH in AMA-induced Calu- 6 cell death and investigated whether ROS scavengers were able to rescue Calu-6 cells from AMA-induced apoptosis since we have previously observed that AMA inhibited the growth of Calu- 6 cells by inducing a G1 arrest of the cell cycle and by triggering apoptosis (unpublished data).

AMA can disturb the natural oxidation/reduction equilibrium in cells by causing a breakdown in the mitochondrial membrane potential $\left(\Delta \Psi_{\mathrm{m}}\right)(13,15,17)$. It is reported that the increased intracellular $\mathrm{H}_{2} \mathrm{O}_{2}$ played an important role in AMA-induced cell death in liver $(38,39)$ and A549 human 
A

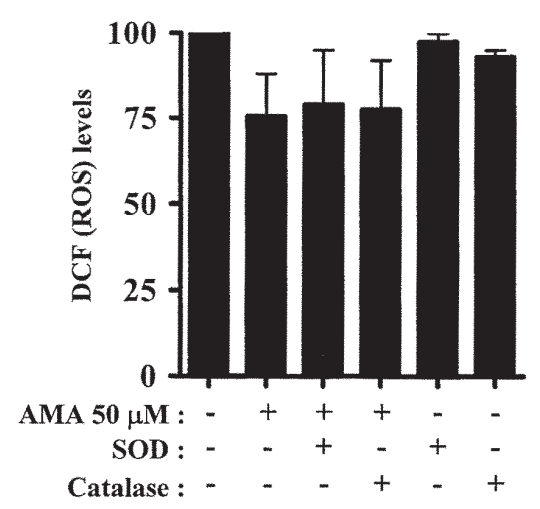

D

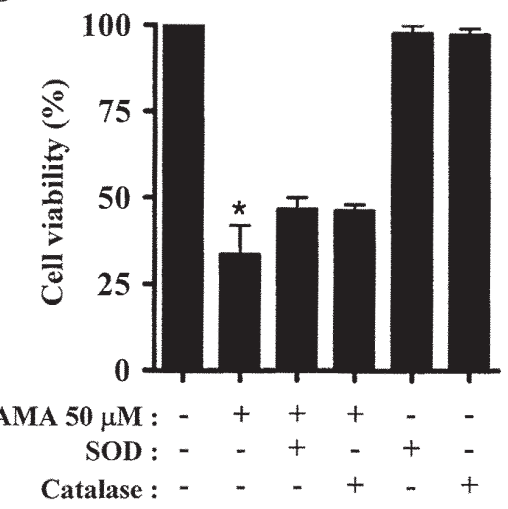

B

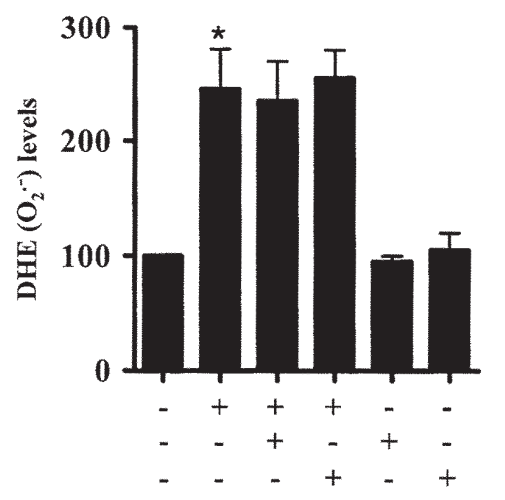

E

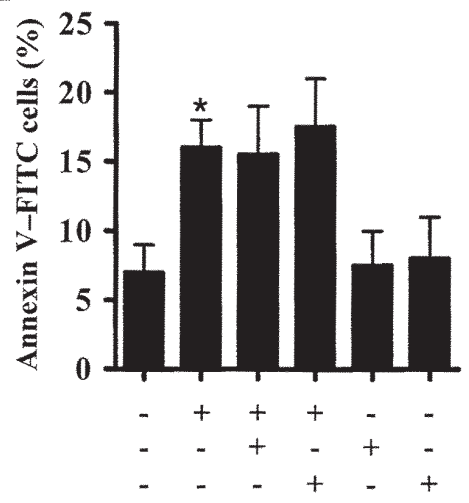

C

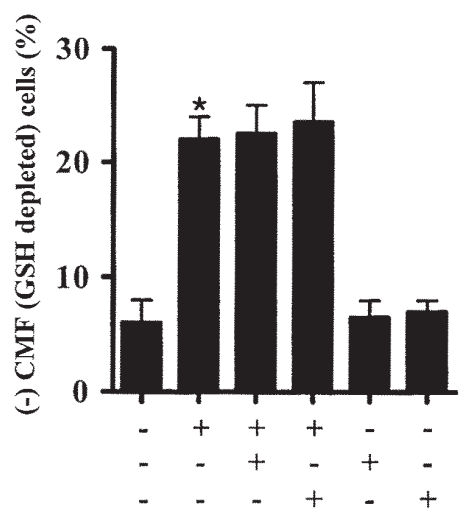

F

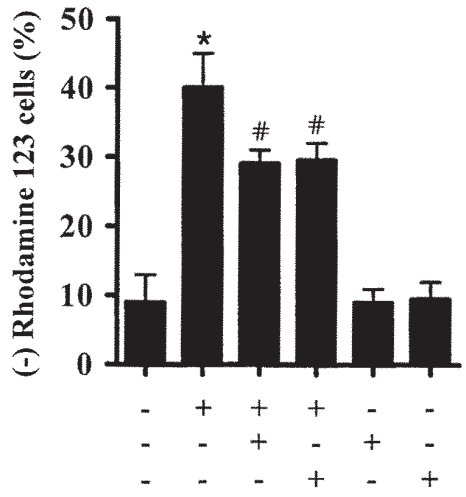

Figure 6. Effect of SOD or catalase on ROS levels, GSH depletion and cell viability in AMA-treated Calu-6 cells. Exponentially-growing cells were treated with SOD $(30 \mathrm{U} / \mathrm{ml})$ or catalase $(30 \mathrm{U} / \mathrm{ml})$ in addition to $50 \mu \mathrm{M}$ AMA for $72 \mathrm{~h}$. The graphs show (A) the levels of mean DCF fluorescence, (B) mean DHE fluorescence (\% of control cells) and (C) the CMF-negative fluorescence (GSH depleted) cell percentages. (D) The viability of Calu-6 cells was assessed by MTT assay. (E and F) The graphs show the annexin V-positive and Rhodamine 123-negative cell percentages. ${ }^{*} \mathrm{P}<0.05$ as compared with the control group cells. ${ }^{\#} \mathrm{P}<0.05$ as compared with cells treated with only AMA.

lung cancer cells (18). Similarly, treatment with $100 \mu \mathrm{M}$ AMA strongly reduced the viability of Calu- 6 cells and increased the non-specific ROS (DCF) level. An increase in intracellular ROS levels was also observed within $10 \mathrm{~min}$ in AMA-treated Calu- 6 cells. These results suggest that the increased ROS levels by AMA are correlated with cell death. However, the intracellular ROS levels were decreased in Calu- 6 cells treated with low doses of AMA $(10,25$ or $50 \mu \mathrm{M})$ at $72 \mathrm{~h}$. Tiron, which protected some Calu- 6 cells against AMA insult, intensified the decreased levels of ROS in these cells. We have also recently reported that the increase of the intracellular ROS levels in AMA-treated As4.1 juxtaglomerular cells is not closely related to apoptosis (22). Therefore, the exact cell death mechanism through the intracellular ROS in AMA-treated cells is controversial. AMA inhibits succinate and NADH oxidase and the mitochondrial electron transport between cytochromes $b$ and $\mathrm{c}$ (13-16), which may result in $\mathrm{O}_{2}{ }^{-}$production at the mitochondria. According to our data, the level of the intracellular $\mathrm{O}_{2}{ }^{-}$- was significantly increased in AMA-treated cells at the early or late times. This increase likely resulted from the production of $\mathrm{O}_{2}{ }^{-}$at the mitochondria in AMA-treated Calu- 6 cells rather than the decreased activity of SOD, since SOD activity was increased by treatment with AMA at $72 \mathrm{~h}$. Although we cannot explain the exact mechanism resulting in AMA increasing SOD activity at $72 \mathrm{~h}$, it is possible that $\mathrm{O}_{2}{ }^{\circ}$ production from mitochondria damaged by AMA triggers SOD expression and its activity. The $\mathrm{O}_{2}{ }^{-}$levels of AMA markedly increased within $10 \mathrm{~min}$ in a dose-dependent manner. The increase of $\mathrm{O}_{2}{ }^{-}$levels at the early time points was probably from the decreased activity of SOD as well as the production of $\mathrm{O}_{2}{ }^{-}$at the mitochondria. These data suggest that the accumulation of $\mathrm{O}_{2}{ }^{-}$levels due to the production of itself and/or changes of SOD activity is time-dependent. In particular, the increase of catalase activity by AMA at $1 \mathrm{~h}$ did not reduce intracellular ROS (DCF) levels, while the decreased activity of catalase at $72 \mathrm{~h}$ did not increase the ROS levels. Therefore, the changes of ROS levels in AMA-treated Calu-6 cells appear to be regulated by other factors such as SOD and GSH peroxidase rather than catalase. The increased $\mathrm{O}_{2}{ }^{\circ-}$ levels by AMA were observed in human lung epithelial (40) and As4.1 juxtaglomerular cells (22). These data suggest that the apoptotic effects of AMA are comparative to the changes of the intracellular $\mathrm{O}_{2}{ }^{-}$levels. This notion was supported by the result that tiron, showing the reduction of the intracellular $\mathrm{O}_{2}{ }^{-}$levels, slightly inhibited AMA-induced cell death. Trimetazidine, SOD or catalase showed no reduction of $\mathrm{O}_{2}{ }^{-}$ levels in AMA-treated cells and did not decrease apoptosis in these cells. However, tempol, another $\mathrm{O}_{2}{ }^{--}$scavenger did not 
affect apoptotic levels in AMA-treated Calu-6 cells. We observed that caspase- 3 and -8 inhibitors, which showed antiapoptotic effects on AMA-treated Calu-6 cells, did not significantly reduce $\mathrm{O}_{2}{ }^{-}$levels (unpublished data). The exact cell death mechanism through intracellular $\mathrm{O}_{2}{ }^{-}$in AMAtreated cells needs to be defined further.

Interestingly, tiron significantly prevented loss of the mitochondrial transmembrane potential $\left(\Delta \Psi_{\mathrm{m}}\right)$ while tempol, which showed the decreased effects on $\mathrm{O}_{2}{ }^{-}$levels in AMAtreated cells, slightly prevented the loss $\left(\Delta \Psi_{\mathrm{m}}\right)$. Since it is known that tempol and tiron are SOD-mimics (33-35), it is possible that tempol and tiron play a role in protecting mitochondria via scavenging the $\mathrm{O}_{2}{ }^{*}$ generated from mitochondria in AMA-treated cells rather than in preventing apoptosis resulting from entire cell damage by AMA. In addition, treatment with exogenous SOD or catalase significantly inhibited loss of the mitochondrial transmembrane potential $\left(\Delta \Psi_{\mathrm{m}}\right)$ induced by AMA. These results suggest the possibility that exogenous SOD and catalase scavenge the extracellular ROS released from AMA-treated cells, thereby blocking down the detrimental autocrine effects of ROS on mitochondria in these cells.

It has been reported that the intracellular GSH content has a decisive effect on anticancer drug-induced apoptosis, indicating that apoptotic effects are inversely comparative to GSH content $(41,42)$. Similarly, our result clearly indicated the depletion of the intracellular GSH content following treatment with AMA in Calu-6 cells at $72 \mathrm{~h}$. We have shown that many of the negative CMF fluorescence (GSH depletion) cells were considered to be dead, as evidenced by PI-positive staining. No effect of tempol, trimetazidine, SOD or catalase on preventing apoptosis in AMA-treated cells likely resulted from their failure of the recovery of GSH depletion. These results support that the intracellular GSH levels are tightly related to AMA-induced cell death. However, tiron which showed an anti-apoptotic effect in AMA-treated cells, also failed to recover the GSH depletion in these cells. These results suggest that AMA-induced Calu- 6 cell death is mediated by ROS changes as well as GSH content alteration. In relation to the cell cycle distribution following treatment with AMA and ROS scavengers including SOD and catalase, ROS scavengers except tempol did not alter a G1 phase accumulation during the cell cycle induced by AMA (data not shown), suggesting that changes in ROS levels and GSH contents by these scavengers are not closely correlated with cell cycle regulation in Calu-6 cells.

In summary, AMA strongly generated intracellular $\mathrm{O}_{2}{ }^{-}$ and induced the depletion of GSH content in human lung Calu- 6 cells. Treatment with tiron showing the decreasing effect on $\mathrm{O}_{2}{ }^{*}$ levels in AMA-treated cells significantly prevented apoptosis in these cells. Our results suggest that the changes of intracellular ROS including $\mathrm{O}_{2}{ }^{-}$and $\mathrm{GSH}$ affect apoptosis in AMA-treated Calu-6 cells.

\section{Acknowledgements}

This work was supported by the Korea Research Foundation Grant funded by the Korean Government (KRF-2008-331E00048.

\section{References}

1. Zorov DB, Juhaszova M and Sollott SJ: Mitochondrial ROSinduced ROS release: An update and review. Biochim Biophys Acta 1757: 509-517, 2006.

2. Simon HU, Haj-Yehia A and Levi-Schaffer F: Role of reactive oxygen species (ROS) in apoptosis induction. Apoptosis 5: 415-418, 2000.

3. Gonzalez C, Sanz-Alfayate G, Agapito MT, Gomez-Nino A, Rocher A and Obeso A: Significance of ROS in oxygen sensing in cell systems with sensitivity to physiological hypoxia. Respir Physiol Neurobiol 132: 17-41, 2002.

4. Wilcox CS: Reactive oxygen species: roles in blood pressure and kidney function. Curr Hypertens Rep 4: 160-166, 2002.

5. Poot M, Teubert H, Rabinovitch PS and Kavanagh TJ: De novo synthesis of glutathione is required for both entry into and progression through the cell cycle. J Cell Physiol 163: 555-560, 1995.

6. Schnelldorfer T, Gansauge S, Gansauge F, Schlosser S, Beger HG and Nussler AK: Glutathione depletion causes cell growth inhibition and enhanced apoptosis in pancreatic cancer cells. Cancer 89: 1440-1447, 2000.

7. Lauterburg BH: Analgesics and glutathione. Am J Ther 9: 225-233, 2002 .

8. Chen TJ, Jeng JY, Lin CW, Wu CY and Chen YC: Quercetin inhibition of ROS-dependent and -independent apoptosis in rat glioma C6 cells. Toxicology 223: 113-126, 2006.

9. Dasmahapatra G, Rahmani M, Dent P and Grant S: The tyrphostin adaphostin interacts synergistically with proteasome inhibitors to induce apoptosis in human leukemia cells through a reactive oxygen species (ROS)-dependent mechanism. Blood 107: 232-240, 2006.

10. Wallach-Dayan SB, Izbicki G, Cohen PY, Gerstl-Golan R, Fine $\mathrm{A}$ and Breuer R: Bleomycin initiates apoptosis of lung epithelial cells by ROS but not by Fas/FasL pathway. Am J Physiol Lung Cell Mol Physiol 290: L790-L796, 2006.

11. Shim HY, Park JH, Paik HD, Nah SY, Kim DS and Han YS: Acacetin-induced apoptosis of human breast cancer MCF-7 cells involves caspase cascade, mitochondria-mediated death signaling and SAPK/JNK1/2-c-Jun activation. Mol Cells 24: 95-104, 2007.

12. Nakayama K, Okamoto F and Harada Y: Antimycin A: isolation from a new Streptomyces and activity against rice plant blast fungi. J Antibiot 9: 63-66, 1956.

13. Campo ML, Kinnally KW and Tedeschi H: The effect of antimycin A on mouse liver inner mitochondrial membrane channel activity. J Biol Chem 267: 8123-8127, 1992.

14. Maguire JJ, Kagan VE and Packer L: Electron transport between cytochrome $\mathrm{c}$ and alpha tocopherol. Biochem Biophys Res Commun 188: 190-197, 1992.

15. Pham NA, Robinson BH and Hedley DW: Simultaneous detection of mitochondrial respiratory chain activity and reactive oxygen in digitonin-permeabilized cells using flow cytometry. Cytometry 41: 245-251, 2000.

16. Alexandre A and Lehninger AL: Bypasses of the antimycin a block of mitochondrial electron transport in relation to ubisemiquinone function. Biochim Biophys Acta 767: 120-129, 1984.

17. Balaban RS, Nemoto S and Finkel T: Mitochondria, oxidants, and aging. Cell 120: 483-495, 2005.

18. Panduri V, Weitzman SA, Chandel NS and Kamp DW: Mitochondrial-derived free radicals mediate asbestos-induced alveolar epithelial cell apoptosis. Am J Physiol Lung Cell Mol Physiol 286: L1220-L1227, 2004.

19. Petronilli V, Penzo D, Scorrano L, Bernardi P and Di Lisa F: The mitochondrial permeability transition, release of cytochrome $c$ and cell death. Correlation with the duration of pore openings in situ. J Biol Chem 276: 12030-12034, 2001.

20. Costantini P, Chernyak BV, Petronilli V and Bernardi P: Modulation of the mitochondrial permeability transition pore by pyridine nucleotides and dithiol oxidation at two separate sites. J Biol Chem 271: 6746-6751, 1996.

21. Pastorino JG, Tafani M, Rothman RJ, Marcinkeviciute A, Hoek JB and Farber JL: Functional consequences of the sustained or transient activation by Bax of the mitochondrial permeability transition pore. J Biol Chem 274: 31734-31739, 1999.

22. Han YW, Kim SZ, Kim SH and Park WH: The changes of intracellular $\mathrm{H}_{2} \mathrm{O}_{2}$ are an important factor maintaining mitochondria membrane potential of antimycin A-treated As4.1 juxtaglomerular cells. Biochem Pharmacol 73: 863-872, 2007. 
23. King MA: Antimycin A-induced killing of HL-60 cells: apoptosis initiated from within mitochondria does not necessarily proceed via caspase 9. Cytometry A 63: 69-76, 2005.

24. Wolvetang EJ, Johnson KL, Krauer K, Ralph SJ and Linnane AW: Mitochondrial respiratory chain inhibitors induce apoptosis. FEBS Lett 339: 40-44, 1994

25. Kaushal GP, Ueda N and Shah SV: Role of caspases (ICE/CED 3 proteases) in DNA damage and cell death in response to a mitochondrial inhibitor, antimycin A. Kidney Int 52: 438-445, 1997.

26. de Graaf AO, Meijerink JP, van den Heuvel LP, et al: Bcl-2 protects against apoptosis induced by antimycin $\mathrm{A}$ and bongkrekic acid without restoring cellular ATP levels. Biochim Biophys Acta 1554: 57-65, 2002.

27. Park WH, Han YW, Kim SW, Kim SH, Cho KW and Kim SZ Antimycin A induces apoptosis in As4.1 juxtaglomerular cells. Cancer Lett 251: 68-77, 2007.

28. Petty RD, Nicolson MC, Kerr KM, Collie-Duguid E and Murray GI: Gene expression profiling in non-small cell lung cancer: from molecular mechanisms to clinical application. Clin Cancer Res 10: 3237-3248, 2004.

29. Park WH, Seol JG, Kim ES, et al: Arsenic trioxide-mediated growth inhibition in MC/CAR myeloma cells via cell cycle arrest in association with induction of cyclin-dependent kinase inhibitor, p21, and apoptosis. Cancer Res 60: 3065-3071, 2000.

30. Macho A, Hirsch T, Marzo I, et al: Glutathione depletion is an early and calcium elevation is a late event of thymocyte apoptosis. J Immunol 158: 4612-4619, 1997.

31. Hedley DW and Chow S: Evaluation of methods for measuring cellular glutathione content using flow cytometry. Cytometry 15 349-358, 1994.

32. Park WH, Jung CW, Park JO, et al: Trichostatin inhibits the growth of ACHN renal cell carcinoma cells via cell cycle arrest in association with p27, or apoptosis. Int J Oncol 22: 1129-1134, 2003.
33. Yamada J, Yoshimura S, Yamakawa H, et al: Cell permeable ROS scavengers, tiron and tempol, rescue PC12 cell death caused by pyrogallol or hypoxia/reoxygenation. Neurosci Res 45: $1-8,2003$

34. Mitchell JB, Samuni A, Krishna MC, et al: Biologically active metal-independent superoxide dismutase mimics. Biochemistry 29: 2802-2807, 1990.

35. Ledenev AN, Konstantinov AA, Popova E and Ruuge EK: A simple assay of the superoxide generation rate with Tiron as an EPR-visible radical scavenger. Biochem Int 13: 391-396, 1986.

36. Tikhaze AK, Lankin VZ, Zharova EA and Kolycheva SV: Trimetazidine as indirect antioxidant. Bull Exp Biol Med 130: 951-953, 2000

37. Stanley WC and Marzilli M: Metabolic therapy in the treatment of ischaemic heart disease: the pharmacology of trimetazidine. Fundam Clin Pharmacol 17: 133-145, 2003.

38. Chen HM, Ma HH and Yan XJ: Inhibitory effect of agarohexaose on antimycin A induced generation of reactive oxygen species. Yao Xue Xue Bao 40: 903-907, 2005.

39. Chen HM and Yan XJ: Antioxidant activities of agaro-oligosaccharides with different degrees of polymerization in cellbased system. Biochim Biophys Acta 1722: 103-111, 2005.

40. Li C, Wright MM and Jackson RM: Reactive species mediated injury of human lung epithelial cells after hypoxia-reoxygenation. Exp Lung Res 28: 373-389, 2002.

41. Estrela JM, Ortega A and Obrador E: Glutathione in cancer biology and therapy. Crit Rev Clin Lab Sci 43: 143-181, 2006.

42. Higuchi Y: Glutathione depletion-induced chromosomal DNA fragmentation associated with apoptosis and necrosis. J Cell Mol Med 8: 455-464, 2004. 